\title{
A Cross-Sectional Study on Visual Art Students' Perceptions of the Assessment Experience in a Public Higher Education in Ghana
}

\author{
Eshun, Eric Francis (Corresponding author) \\ Department of Communication Design, Faculty of Art \\ College of Art \& Built Environment \\ Kwame Nkrumah University of Science \& Technology, Kumasi, Ghana \\ Tel: 233-249-120-625Ｅ-mail: efeshun.art@knust.edu.gh
}

Fiagbor, Lewis

Department of Communication Design, Faculty of Art

CABE, KNUST, Kumasi, Ghana

Received: July 28, 2018

Accepted: December 4, 2018

Published: June 21, 2019

doi:10.5296/gjes.v5i1.13437

URL: https://doi.org/10.5296/gjes.v5i1.13437

\begin{abstract}
This study explores visual arts students' perceptions of their assessment experience in a public university in Ghana which offers undergraduate degree programmes across the disciplines in Visual Art. A convenient sampling technique was used to pool 600 volunteered respondents out of a student's population of 2,618 from the Faculty of Art, Kwame Nkrumah University Science \& Technology, Kumasi. Data was collected during the second semester of 2015/2016 academic year using a face validated 20 item five-point Likert scale Students' Assessment Experience Questionnaire with reliability estimate of .744. Data collected was analyzed using descriptive statistics and one-way MANOVA analysis. The findings of the study pointed to the significant difference between the various visual art departments in their satisfaction with the assessment delivery and experience. The results did not show significant gap between student's perceptions of assessment experience across the disciplines (departmental) level. There was no significant difference between students in their total satisfaction with the assessment delivery and assessment experience. However there were significant difference along receiving of feedback and assessment of artworks. Based on the
\end{abstract}




\section{Macrothink}

Global Journal of Educational Studies

ISSN 2377-3936

findings, it is recommended that innovative assessment practices should be encouraged across the disciplines to foster creativity and deepen life-long skills among the students.

Keywords: Assessment, Students' perspectives, Visual art assessment practices, Higher education, Feedback 


\section{Introduction}

The importance of assessment in education cannot be underestimated (Black \& Wiliam, 1998). Consequently, the need for the adoption of an effective assessment practice (in especially higher education) that ensures that teaching and learning lives up to expectations in dealing with the aspirations of society. Banta (2004) notes that an effective assessment programme should be based on the outcomes for student learning and development that faculty and other stakeholders believe to be important. He further argues that when the lesson objectives are aligned to outcomes it is easier to determine the type of assessment practice(s) that are most appropriate to support learning. Banta (2004) sharpened and extended this point by noting that a poorly designed assessment practice has the potential to hinder effective student learning and thereby stifle curriculum innovation. Boud, Cohen, and Sampson (1999) argue that inappropriate assessment practices are unhelpful and breeds competition within and between students and consequently prevent groups functioning effectively instead of encouraging collaborative learning among students.

This exploratory study on visual art students' perceptions of their assessment environment, opens the way for further studies on assessment practices involving both instructors and students in Ghana. The findings have implications for Art and Design instructions, curriculum and studio environment.

\section{Literature}

Several studies have shown that assessment impact directly on student's on learning (Cohen \& Sampson, 1999; Hamdorf \& Hall, 2001; Biggs, 2003; Race et al., 2005). Further claims by Boud and Associates (2010) and Drew and Shreeve (2005) show that the mode of assessing students' learning has a very powerful influence on the learning behaviour of the students. The need for appropriate assessment practice(s) in higher education has obviously become more important (Eca, 2002). On assessment environment, Van den Bergh et al. (2006) discovered that integrating learning, instruction and assessment in problem-based learning is unavoidable, likewise, students demand transparency, explicitness about the assessment procedure and would like the instructors to assess more uniformly - objectivity, transparency and standardization. This comes touching the backdrop been proposed that other assessment practices such as formative assessment; peer assessment and self-assessment, if made part of the pedagogy to complement the traditional teacher-centered summative assessment in higher education could aid the acquisition of the needed knowledge and lifelong skills (Black \& Wiliam, 1998; Boud \& Associates, 2010). In their study, Van den Bergh et al. (2006) noted that students expect assessment to be formative as well as summative.

Furthermore, recent studies suggest the need for educational authorities to involve students in the educational process: in determining learning goals, instruction and assessment practices (Rust, 2002; Sluijsman, 2002; Struyven, Dochy, \& Janssens, 2005; Race, 2009). Consequently, other studies suggest students' involvement should be directed and students have to be adequately prepared for the selected assessment practice(s) for effective assessment process (Race, 2002; Eshun \& de Graft-Johnson, 2011; Craddock \& Mathias, 2009). This, they argued would ensure students engagement. Hassanpour et al. (2011) 
conclude that when assessment of students' achievement is contextualize within learning and teaching process, that is in the form of evaluation and assessment, it encourages students to adopt to deep learning strategies especially in art and architecture studios.

\subsection{Assessment in Visual Art}

Studies on assessment in art and design education show that most of the assessment practices used in the art college encourage rote learning rather than promoting art skills acquisition and creativity (Eca, 2002; Eshun \& Osei-Poku, 2012). Eisner (2002) gives five reasons for the difficulty in assessing visual arts students; with the most striking being the fact that visual arts assessment is dependent on judgments of the quality and craftsmanship of a student's work. He also indicates that the arts focus on the experience of creating art and that experience cannot be quantified, making measurement seemingly incompatible. The worrying fact is that whiles there are clear objectives of art and design education there are no defined curriculum structures as seen in other science disciplines.

Eca (2002) suggests that since visual arts foster creativity, the assessment practices in creative arts should be framed around the theories of creativity and within the creative process. However, theories of creativity increase the subjectivity and bias controversies. Gordon (2004) and Mckillop (2004) note that since previous experience and knowledge do affect the way we think about, interpret and perceive an art work, the issue of subjectivity dominates assessment in visual arts. In some cases, assessment in art and design has focused on the quality of the artifact (product) very often summative rather than what the student has learnt during the process of producing (creative process) which could be formative (Mckillop, 2004), resulting in a surface approach to learning where pleasing the instructor is the motivation. There has also been an assumption that only instructors are reliable and experienced enough to make judgments on students' work. Eshun and de Graft-Johnson (2011) point to 'who' is carrying out the assessment and with what measure as another challenge concerning art assessment.

Various authors have also commented on the assessment in design with varying emphasis on the person, process and product (Ellmers, 2006; Lindström, 2006; Goldschmidt, 2003; Ehmann, 2005). The concern of validity is seen as a challenge. Balchin (2005) has observed that in many cases, the evidence for their ability and reliability is incomplete or not fully satisfactory. For Balchin (2005) it would be necessary to develop a complex composite of several instruments for any particular assessment, based especially around the 4 P's (product, process, person, and press (promoters/providers). Gilio and du Toit (2013) are of the view that design courses offer structures that support formative assessment rather than summative assessment. Eca (2002) proposed that since the artistic process is not a linear progression but is constructed on interaction of the thinking process and experimentation. A simple deduction on the assessment model and practice cannot be used but rather a holistic approach to assessment that reflects on the process, realties and intangibilities are important.

Nonetheless, students need to learn the skills which will enable them to assess qualities such as creativity in a subject area where judgments can be highly subjective. A student in art and design invests a great deal of their self and personal experience into their work, so it is important to understand how they feel about having their work assessed. This can somehow 
lead to tension between objective measurement and the subjective and personal qualities of their work.

\subsection{Feedback}

In visual art studio pedagogy, feedback is the bedrock of the problem solving process. At each stage of the process, both informal and formal feedbacks are timely injected to lubricate the learning wheels from peers and instructors as well. Blair (2011) notes that the use and importance of feedback in art and design education dates back to many centuries; its use is well established and integrated into the studio pedagogy. Similarly, other studies by Annie (2011), Willems (2009), Harvey (2001) and Pokorny and Pickford (2010) have re-echoed the importance of feedback and the challenges associated with its use in the learning process, Race (2002) who sees feedback as the lubricant in the learning process argued that assessors sometimes are too busy assessing and fail to give really useful feedback to the students.

However, there are doubt its full usefulness especially written feedback to the student. Spiller (2009) commented on the divergent views expressed by both students and teachers on feedback. Annie (2011) comparing the impact of positive and negative feedback on students' learning concluded that positive feedback has the tendency to motivate students to achieve better learning engagement, against an equally devastating negative feedback. Conversely but ironically, students are too busy getting ready for their next assessment to the extent that they fail to take any notice of feedback from the previous assessment. Harvey (2001) holds that in all types of feedback associated with academia, students are important stakeholders and play a pivotal role in the feedback cycle; hence their views are essential (Alderman et al., 2012). Brown (2005) reckons that "if assessment is to be integral to learning, feedback must be at the heart of the process."

In this paper we report on students' perceptions about their assessment experiences and teacher support during their undergraduate years and how those perceptions vary across courses and academic levels. Our objective is to determine consistent patterns across a range of Ghanaian higher education visual art programmes. A particular emphasis was placed on identifying any perceptional differences among minority women compared to majority males, since it has been observed that the females have been traditionally underrepresented in visual art higher education in Ghana as compared to the Western world (Eurydice, 2010) and, have been shown to be at higher risk of leaving the art and design or creative related professions (Dalton, 2001; Satterfield et al., 2010) also likely due to unfair assessment practices (Moss \& Gunn, 2007).

Current status and level of perception of assessment practice in art and design higher education need to be uncovered. This study attempt to find out the extent of how visual art students in tertiary institution in Ghana perceive their assessment experiences, with respect to assessment practice, feedback, and assessment of artwork. This also is in a way to know area(s) or dimension(s) that can potentially be improved. The following research questions were therefore formulated:

\subsection{Research Questions}


1) What is the level of assessment experience of higher education visual art students?

2) What are the differences, if any; of visual arts students' use and acceptance of assessment practices depending upon their art discipline choice experience?

\section{Methodology}

\subsection{Cross-Institutional Study}

The population of study came from the Faculty of Art, University of Science \& Technology in Kumasi, Ghana. The year of the study was 2015/2016 academic year. The study targeted 800 students using simple convenient sampling from all the academic disciplines (Departments) of the faculty. The disciplines (departments) are classified under the following: Communication Design, Industrial Arts and Integrated Rural Art \& Industry; Painting and Sculpture; and Publishing Studies. The departments varied in student sample size as shown in Table 2. All participants of the survey voluntarily offered their opinions with non-disclosure agreement. They had at least experienced one full semester at the institution. The instrument was administered at the end of the second semester. The participants were thoroughly briefed on the items of the questionnaire were consequently administered by assistants to the respondents at the end of a class sessions. The administration was done on departmental bases. Out of the 600 questionnaires that were dispensed, 524 were returned constituting a return rate of $87.3 \%$. Out of the 524 respondents in the study, 299 were males representing $57.1 \%$ and 225 females representing $42.9 \%$.

\subsection{Measure}

A modified 20-item Assessment Experience self-administered survey instrument was used. The first part of the instrument had demographic items about respondents' age, sex, department and level was collected with the second part having items bordering on assessment practices: assessment training, assessment feedback, assignment and learning and assessment of artworks. Respondents were asked to state their level of agreement of each statement for three dimensions of assessment practices in education on a five-point Likert scale (1 represent "strongly disagree" to 5 represent "strongly agree"; 3 denotes average, where the mid-point 3 can be seen as a neutral position, and a mean value above this can be seen to be positive and a mean rating below 3 is negative). The scale is 5 point, higher score indicate agreement with that item and lower scores indicate disagreement with that item. Items with a mean score of $\geq 4.5$ are true positive points; those with a mean of $\leq 3$ are problem areas; scores in between these two limits indicate aspects of the environment that could be enhanced. The modified instrument was subjected to face and content validity by experts. After the modification of the instrument, a pre-test was carried out on 25 students from a different faculty in the university. After a trial, the modified instrument was administered on a set of student who did not participate in the trial. The overall reliability of the data was calculated yielding Cronbach's alpha coefficient of 0.744 for the 20 items. 


\section{Macrothink}

Global Journal of Educational Studies

ISSN 2377-3936 2019, Vol. 5, No. 1

Table 1. Dimensions of assessment experience questionnaire

\begin{tabular}{|c|c|c|c|}
\hline Domain & Description & No. & Sample Item \\
\hline $\begin{array}{l}\text { Assessment } \\
\text { Practice }\end{array}$ & $\begin{array}{l}\text { Extent to which teachers use } \\
\text { different assessment task on } \\
\text { various situations }\end{array}$ & 11 & $\begin{array}{l}\text { Lecturers involve us in the assessment } \\
\text { process by involving us in deciding } \\
\text { learning objectives, assessment criteria, } \\
\text { and through assessment practices such } \\
\text { as self and peer assessment. }\end{array}$ \\
\hline $\begin{array}{l}\text { Assessment } \\
\text { Feedback }\end{array}$ & $\begin{array}{l}\text { The extent to which students } \\
\text { receive and use feedback in } \\
\text { their learning }\end{array}$ & 4 & $\begin{array}{l}\text { Lecturers make sure we take their } \\
\text { feedback seriously and apply them in } \\
\text { later assignments. }\end{array}$ \\
\hline $\begin{array}{l}\text { Assessment } \\
\text { of Artworks }\end{array}$ & $\begin{array}{l}\text { The extent to which students } \\
\text { perceive assessment practices } \\
\text { to be effective }\end{array}$ & 5 & $\begin{array}{l}\text { Assessment of students of the arts is } \\
\text { more difficult than assessment of } \\
\text { students of other disciplines. }\end{array}$ \\
\hline
\end{tabular}

Overall, our intention was for the instrument to be brief, clear, unambiguous, and individually completed in less than 10 minutes, requiring minimal assistance or explanation. The data was analyzed using SPSS 16.0 for descriptive statistics. For inferential statistics, GLM Univariate - MANOVA was employed. The data was visually scanned to check for errors before statistical analyses were performed. For each dimension, non-parametric statistics were employed to identify gender, age and academic level differences and to then see if such differences were consistent across the spectrum of participants. This enabled us to identify trends and possible trends.

\section{Results and Discussions}

The descriptive analysis shows the demographic characteristics of respondents with their departments. There were no missing values in response. Overall, about 25.4 percent of the students were in graduation year. About 27.8 percent students are 18-20 years old, 35.2 percent are between 21-23 years old, 30.9 percent are between 24-26 years old and 6.1 percent are more than 27 years old. Tables 2.1 and 2.2 provide demographic statistics of the respondents from participating departments.

Table 2. Sample distribution of the disciplines (departments)

\begin{tabular}{lccc}
\hline Department & Male & Female & Total \\
\hline Communication Design & $68(61.8)$ & $42(38.2)$ & 110 \\
Painting and Sculpture & $49(49.5)$ & $50(50.5)$ & 99 \\
Integrated Rural Arts and Industry & $55(53.4)$ & $48(46.3)$ & 103 \\
Publishing Studies & $65(60.2)$ & $43(39.8)$ & 108 \\
Industrial Art & $62(59.6)$ & $42(40.4)$ & 104 \\
\hline Total & $299(57.1)$ & $225(42.9)$ & 524 \\
\hline
\end{tabular}


Table 3. Academic level distribution of students from selected departments

\begin{tabular}{lcc}
\hline Academic Level & No. & Percentage \\
\hline Level 1 & 122 & 23.3 \\
Level 2 & 147 & 28.0 \\
Level 3 & 120 & 22.9 \\
Level 4 & 135 & 25.8 \\
\hline Total & 524 & 100.0 \\
\hline
\end{tabular}

RQ 1: What is the level of assessment experience of higher education visual art students?

The descriptive statistics Table 4 shown below, provides the mean and standard deviation for the three different dependent variables, which have been split by the independent variable.

Table 4. Level of assessment experience of higher education visual art students

\begin{tabular}{llccc}
\hline Dimension & Art Disciplines of Respondent & Mean & SD & N \\
\hline \multirow{5}{*}{ Feedback } & Communication Design & 3.243 & .802 & 110 \\
& Painting and Sculpture & 2.919 & .861 & 99 \\
& Integrated Rural Arts and Industry & 2.818 & .966 & 103 \\
& Industrial Arts & 2.993 & .810 & 104 \\
& Publishing Studies & 3.287 & .923 & 108 \\
\cline { 2 - 5 } Assessment of & Total & 3.058 & .890 & 524 \\
\hline \multirow{5}{*}{ Artworks } & Communication Design & 3.524 & .763 & 110 \\
& Painting and Sculpture & 3.640 & .639 & 99 \\
& Integrated Rural Arts and Industry & 3.429 & .628 & 103 \\
& Industrial Arts & 3.506 & .798 & 104 \\
& Publishing Studies & 3.417 & .758 & 108 \\
\cline { 2 - 5 } Assessment of & Total & 3.502 & .724 & 524 \\
\hline Practices & Communication Design & 3.270 & .522 & 110 \\
& Painting and Sculpture & 3.170 & .563 & 99 \\
& Integrated Rural Arts and Industry & 3.185 & .480 & 103 \\
& Industrial Arts & 3.187 & .590 & 104 \\
& Publishing Studies & 3.199 & .552 & 108 \\
\cline { 2 - 5 } & Total & 3.204 & .542 & 524 \\
\hline
\end{tabular}

The above table shows that taken together, the assessment experience of higher education visual art students is moderately high. However, dimensional analysis of the data shows that "Feedback" are below the scale mean of 3.0, indicating that this is not adequately taken care of in the assessment experience in some visual art disciplines. While "assessment of artwork" has the highest mean score among all the three dimensions, followed by "assessment practice". 
Hypothesis: Higher education visual art students will not differ significantly in their overall mean rating of visual art assessment experience.

Table 5. Test of mean difference between visual arts disciplines on assessment experience

\begin{tabular}{|l|l|c|c|c|c|}
\hline & & Mean Difference & df & t & p-value \\
\hline Overall Assessment Experience & Between Groups & 2.486 & 519 & 2.342 & .054 \\
\hline
\end{tabular}

The above table shows that at 0.05 significance level, $\mathrm{df}=519, \mathrm{t}(2.342)$ and $P>0.05$, the null hypothesis of no significant difference was supported. Therefore, the overall mean rating of communication design $(\mathrm{M}=3.345, \mathrm{SD}=.4897)$ does not differ significantly from overall mean rating of assessment experience of Industry Arts (M=3.229, SD=.5976), Publishing Studies $(\mathrm{M}=3.301, \mathrm{SD}=.5328)$, Painting \& Sculpture $(\mathrm{M}=3.243, \mathrm{SD}=.4406)$. However, there was significant difference of the overall mean rating of communication design $(\mathrm{M}=3.345$, $\mathrm{SD}=.4897)$ and Integrated Rural Art \& Industry $(\mathrm{M}=3.144, \mathrm{SD}=.4990) \mathrm{p}>.05$.

RQ 2. What are the differences, if any; of visual arts students' use and acceptance of assessment practices depending upon their visual art discipline choice experience?

A one-way multivariate analysis of variance (MANOVA) was conducted to examine research question 1 that there would be one or more mean differences between specialized visual arts departments and assessment experience scores. A statistically significant MANOVA effect was obtained, $F(12,1.326)=2.934, p<.0005$; Wilk's $\Lambda=0.933$, partial $\eta^{2}=.023$. The multivariate effect size was estimated at .023 , which implies that $2.3 \%$ of the variance in the canonically derived dependent variable was accounted for by specialized departments. Therefore, we can conclude that students' assessment experience was significantly dependent on which department they belong $(p<.0005)$. Further test show that there was a statistically significant difference in Perceptions of the Assessment Experience based on a student's department, $F(12,1.326)=2.934, p<.0005$; Wilk's $\Lambda=0.933$, partial $\eta^{2}=.023$. The Tests of Between-Subjects Effects show that the department the respondents belong has a statistically significant effect on both Feedback $\left(F(4,503)=4.48 ; p<.0005\right.$; partial $\left.\eta^{2}=.034\right)$ and Assessment practices scores $\left(F(2,503)=4.66 ; p<.0005\right.$; partial $\left.\eta^{2}=.04\right)$ and not on Assessment of Artworks $\left(F(4,503)=1.288 ; p=.274\right.$; partial $\left.\eta^{2}=.010\right)$. 
Table 6. A multivariate analysis of variance (MANOVA) between groups

\begin{tabular}{llccccc}
\hline & & Sum of Squares & df & Mean Square & F & Sig. \\
\hline Assessment Practice & Between Groups & .666 & 4 & .166 & .565 & .688 \\
& Within Groups & 152.815 & 519 & .294 & & \\
& Total & 153.481 & 523 & & & \\
Assessment Feedback & Between Groups & 17.722 & 4 & 4.431 & 5.796 & .000 \\
& Within Groups & 396.719 & 519 & .764 & & \\
& Total & 414.441 & 523 & & & \\
Assessment of Artwork & Between Groups & 3.283 & 4 & .821 & 1.573 & .180 \\
& Within Groups & 270.756 & 519 & .522 & & \\
& Total & 274.039 & 523 & & & \\
\hline
\end{tabular}

A follow up of these significant ANOVAs with Tukey's HSD post-hoc tests in the Multiple Comparisons table shows that for mean scores for feedback were statistically significantly different between Department of Communication Design and Department of Integrated Rural Arts and Industry $(p<.0005)$; and Department of Integrated Rural Arts and Industry and Department of Publishing Studies $(p<.0005)$, but not between Department of Communication Design and Department of Painting and Sculpture $(p=.392)$; Department of Communication Design and Department of Industrial Arts $(p=.135)$; Department of Communication Design and Department of Publishing Studies $(p=.131)$. Mean assessment of artworks scores were not statistically significantly different between all the department $(p>.0005)$.

The Multiple Comparisons also shows that for mean scores for assessment of practice were statistically significantly different between Department of Communication Design and Department of Painting and Sculpture $(p<.0005)$, and Department of Publishing Studies and Department of Painting and Sculpture $(p<.0005)$, but not between Department of Communication Design and Department of Integrated Rural Arts and Industry $(p=.059)$. Department of Communication Design and Department of Industrial Arts $(p=.120)$ and Department of Communication Design and Department of Publishing Studies $(p=.993)$.

\subsection{Perception of Assessment Practice}

The results from this domain were also positive and quite moderate, it collaborate an earlier study by Eshun and Adu-Agyem (2010), that some art and design instructors had tried various methods to enhance assessment practices in the same institution. This finding is also consistent with the study done by Hanover Research (2013), where results indicated that faculty using innovative assessment practices pay attention and explicit in communicating learning outcomes and expectations to students, and are thoughtful in aligning learning outcomes with valid assessment tools.

The study also sought students' perceptions of their teachers' support for learning. The 
students responded moderately to the three positive items on teacher support to their learning. These responses present a strong advocacy for an enhanced instructor facilitation of student's learning, with support for a strong positive connection between teaching and assessment to promote deep learning. For most students, there is the need to emphasize the connection between assessment and learning success and in addition to class sizes being a contributing factor, it would be prudent to look for other influences that may be constraining teacher's effort. Similarly, the study done by Butcher and Cash (2007) indicated that initial preparation for visual assessment and presentations was essential and attributed the large class-size could be a constraining factor on the teacher's ability to fully support studio teaching and learning.

The current study reports of almost half of the respondents disagreeing with the first and second item propositions. Respondents felt that they barely receive training in evaluation. This result is in sharp contrast with a study by Carless (2015), where architectural students are adequately prepared with evaluative expertise and engaged in dialogic feedback to boast portfolio reviews. We could infer from the results that perceptions of lack of assessment training could imply some negative engagements with assessment tasks (Butcher \& Cash, 2007). This may suggest that either students have a realistically unfavourable opinion of the assessment, or that students, based on their experience, perceive that only a more effort is necessary to meet assessment difficulties.

\subsection{Perception of Feedback}

The act of giving and receiving feedback was considered to be valuable to students' learning and from the responses; there was high sketchy agreement on this fact. Since most lecturers had little difficulty fulfilling this essential requirement in the visual art studio, consequently, some respondents found the process of giving and receiving feedback a bit challenging, especially in large class-size situation; a situation all the departments are facing. This might lead to inadequate teaching and learning resources and limited academic staff. The positive responses show that students appreciate instructors' feedback on their work-in-progress. Annie (2011), Phillips (2014) and Day (2013) reiterate that students' appreciation of feedback can facilitate deep learning, metacognitive and reflection in design-based learning.

The responses indicate that instructors were fair and open-minded and assessed divergent and imaginative thinking. Arguably, studio teachers need to be trained to be moderately subjective to provide constructive feedback that encourages students to be open-mined and take responsibility for their own learning. The ability to give fair and constructive critique is an important skill that sets students on the right path to scholarship and fostering creativity development (Taylor \& McCormack, 2004). Excessively harsh criticism, on the other hand, or lobed-sided arguments of any kind, is considered to be discouraging and damaging to students' self-confidence and creativity. These findings draw attention again to differences in the assessment experience of students. However, the results from this study reveal that students lack opportunities to be involved in either the developing of learning outcomes, assessment criteria or students participating in the assessment process, since almost all departments use teacher-centered pedagogy. 


\subsection{Perception of Assessment of Artwork}

The lowest scores reported for this domain pertained to difficulty in assessing artwork and ambiguity in the definition of "creativity". Many studies report similar concerns (Eshun \& de Graft-Johnson 2011); these difficulties are not insurmountable and should be addressed. Studio instructors should be trained on appropriate art teaching and assessment methods that might drive active learning so that students will be encouraged to take responsibility for their own learning (Saavedra \& Opfer, 2012). Current pedagogical shifts demand active self-directing and life-long learning in the visual art (Brown, 2004-05). Instructors are no longer simply providers of information, but facilitators and providers of school environment that supports the acquisition of attitudes and evaluative skills necessary for studio critiques in professional practice (Carless, 2015). Consequently, students should be involved in the planning, developing and executing the curriculum at the higher education level (Spiller, 2012).

This study found out that the students were practically indifferent towards assessment. This is an indication that they do not undergo any well-structured procedure meant to educate them on how to assess or evaluate an artwork. This kind of condition can be as a result of over-dependency on the teacher to do everything. Findings from the study also indicate that apart from the Department of Communication Design (Eshun \& Osei-Poku, 2012), where peer assessment is introduced to the students, other departments have the instructor as the sole assessor of students' projects.

One crucial finding of this study has to do with the fact that the students generally agree that assessment of artworks come with some form of subjectivity. Eck (2006) claimed art is a matter of individual taste, suggesting that depending on the open-mindedness of an assessor, a student's creative abilities could be improved or thwarted by an assessment (Barz, 2008). Writers such as Eca (2002) and Hargrove (2011) have touted this subjectivity as one of the difficulties that come with assessment of artworks. This study indirectly collaborates with such postulation.

\subsection{Limitations}

This study may have factors that are considered limitations. Possible limitations to the collection of the research data included that only one public university participated, therefore any results needed to be used cautiously as not to infer to other higher education institutions. Another limitation was that the survey was designed for this study and had no documented measures of validity or reliability. The final limitation was that there was no way to determine that the participants' responses were truthful.

\section{Conclusion}

The primary aim of this study was to find out the perceptions of the students of the Faculty of Art of the KNUST about assessment experience in their respective departments. The findings of the study, clearly point to the following conclusions: Generally, the students of the Faculty of Art, KNUST are indifferent towards assessment. Notwithstanding, one or two departments showed signs of a positive perception of assessment preparation, an indication that they do 
receive some form of training in assessment practices. There were some minor disparities regards to feedback and assessment of artworks and an indication of little or no progressive attempt to introduce authentic assessment in their teaching. Further studies would have to be conducted to clarify the prevailing challenges and also involving the instructors in a longitudinal study. However the results still provide useful information for university administrators in decision making. The focus of this research had been on both the acculturated survey as well as the derived methodology.

\section{Acknowledgements}

The authors are grateful to all the students of this institution who contributed by returning filled questionnaires.

\section{References}

Alderman, L., Towers, S., \& Bannah, S. (2012). Student feedback systems in higher education: A focused literature review and environmental. Quality in Higher Education, 18(3), 261-280. https://doi.org/10.1080/13538322.2012.730714

Annie, T. (2011). Exploring Students' Perception of and Reaction to Feedback in School based Assessment. Malaysian Journal of ELT Research, 7(2), 104-147. Retrieved from http://www.melta.org.my

Balchin, T. (2005). Assessing students' creativity: Lessons from research. Higher Education Academy, April, pp. 1-5. Retrieved from http://www.heacademy.ac.uk

Banta, T. W. (2004). Hallmarks of Effective Outcomes Assessment. San Francisco, CA: Jossey-Bass.

Barz, M. (2008). Fostering Student Creativity and Creative Practice with Assessment: A review of practice in a digital media course. Investigations in University Teaching and Learning, 5(1).

Biggs, J. B. (2003). Teaching for quality learning at university (2nd ed.). Buckingham: Society for Research into Higher Education and Open University Press.

Black, P. J., \& Wiliam, D. (1998). Inside the black box: Raising standards through Classroom assessment. Phi Delta Kappan, 80(2), 139-148.

Boud, D., \& Associates. (2010). Assessment 2020: Seven propositions for assessment reform in higher education. Sydney: Australian Learning and Teaching Council.

Boud, D., Cohen, R., \& Sampson, J. (1999). Peer learning and Assessment. Assessment \& Evaluation in Higher Education, 24(4), 413-426. https://doi.org/10.1080/0260293990240405

Brown, S. (2004). Assessment for Learning. Learning and Teaching in Higher Education, 1, 81-89.

Butcher, J., \& Cash, C. (2007). Talkback: The student experience of learning through verbal feedback in the studio. Paper presented at the European league of Institutes of the Arts (ELIA) 
Teacher's Academy. Brighton, UK. 12-14 July.

Carless, D. (2015). Exploring learning-oriented assessment processes. High Education, 69, 963-976. https://doi.org/10.1007/s10734-014-9816-z

Craddocka, D., \& Mathias, H. (2009). Assessment options in higher education. Assessment \& Evaluation in Higher Education, 34(2), 127-140. https://doi.org/10.1080/02602930801956026

Dalton, P. (2001). The gendering of art education: Modernism, identity and critical feminism. Buckingham, Open University Press.

Davies, A. (1997). Assessment and Transferable Skills in Art and Design. Worcester College of Higher Education, UK. Accessed from http://www.city.londonmet.ac.uk/deliberations/Subjects/art_design/index.html

Day, P. (2013). The Art Group Crit. How do you make a Firing Squad Less Scary? Journal of Learning Development in Higher Education, (5), 1-15. Retrieved from http://cet.usc.edu/resources/teaching_learning/assessment.html

Drew, L., \& Shreeve, A. (2005). Assessment as Participation in Practice. The 13th Improving Learning Symposium, Imperial College, London, UK.

Eca, T. (2002). A conceptual framework for art and design external assessment. Paper prepared for the European Conference on Educational Research, University of Lisbon. Retrieved from http://www.leeds.ac.uk/educol/documents/00002283.htm

Eck, L. R. (2006). Evaluation and Assessment in Middle-Level Art Education - Applications of Constructivist Theory. Los Angeles: Institute for Learning Centered Education.

Ehmann, D. (2005). Using assessment to engage graphic design students in their learning experience. In Making a Difference: 2005 Evaluations and Assessment Conference, Sydney and Melbourne, 30 November-1 December, pp. 108-12.

Eisner, E. W. (2002). The Arts and the Creation of Mind. New Haven: Yale University Press.

Ellmers, G. (2006). Assessment practice in the creative arts: Developing a standardized assessment framework. Teaching and learning Scholars Report, Faculty of Creative Arts, University of Wollongong: New South Wales, Australia.

Eshun, E. F., \& Adu-Agyem, J. (2010). Learners Perceptions in Design Critiques: Impact on Creative Development. Journal of Science and Technology, 30(3), 42-50.

Eshun, E. F., \& de Graft-Johnson, K. G. (2011). Learner Perceptions of Assessment of Creative Products in Communication Design. Art, Design \& Communication in Higher Education, 10(1). 87-100.

Eshun, E. F., \& Osei-Poku, P. (2012). Design Students Perspectives on Assessment Rubric in Studio-Based Learning. Journal of University Teaching \& Learning Practice, 10(1). Retrieved from http://ro.uow.edu.au/jutlp/vol10/iss1/8 


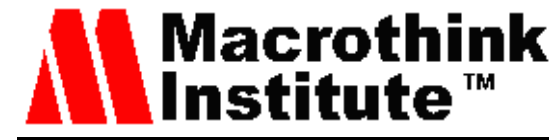

Global Journal of Educational Studies ISSN 2377-3936

Eurydice. (2010). Gender Differences in Educational Outcomes: Study on the Measures Taken and the Current Situation in Europe. Education, Audiovisual and Culture Executive Agency (EACEA P9 Eurydice). Retrieved from http://www.eurydice.org

Giloi, S., \& du Toit, P. (2013). Current Approaches to the Assessment of Graphic Design in a Higher Education Context. International Journal of Art \& Design Education, 32(2), 256-268. https://doi.org/10.1111/j.1476-8070.2013.01758.x

Goldschmidt, G. (2003). Expert knowledge or creative spark? Predicaments in design education. Paper presented at the Expertise in Design, Design Thinking Research Symposium 6, 17-19 November, University of Technology Sydney.

Gordon, J. (2004). The 'wow' factor: The assessment of practical media and creative arts subject. Arts Design \& Communication in Higher Education, 3(1). https://doi.org/10.1386/adch.3.1.61/0

Hamdorf, J. M., \& Hall, J. C. (2001). Surgical Education. Australian and New Zealand Journal of Surgery, 71, 178-83. https://doi.org/10.1046/j.1440-1622.2001.02031.x

Hanover Research. (2013). Best and Innovative Practices in Higher Education Assessment. Washington DC. Retrieved from http://hanoverresearch.com/

Hargrove, R. (2011). Fostering creativity in the design studio: A framework towards effective pedagogical practices. In L. Drew, A. Shreeve, \& L. Lanceley (Eds.), Art, Design and Communication in Higher Education (Vol. 10 No. 1, pp. 7-31).

Harvey, L. (2001). Student Feedback. Centre for Research into Quality. The University of Central England in Birmingham, Birmingham.

Hassanpour, B., Utaberta, N., \& Sirjani, R. (2011). Investigation in Effective Assessment Models in Architecture Design Studios National University Malaysia as Case Study. Australian Journal of Basic and Applied Sciences, 5(9), 571-577.

Lindström, L. (2006). Creativity: What is it? Can you assess it? Can it be taught? International Journal of Art and Design Education, 25(1), 53-66. https://doi.org/10.1111/j.1476-8070.2006.00468.x

Mckillop, C. (2004). Imagining Assessment in Higher Education through online Storytelling and Visual Expressions of Learning. Paper presented at the 3rd International conference of Narative and Interactive Learning Environment, Edinburgh, Scotland.

Moss, G., \& Gunn, R. (2007). Gender Differences in Website Design: Implications for Education. Systemics. Cybernetics and Informatics, 5(6), 38-43.

Phillips, L. (2014). Assessment towards Innovation: Examining Feedback Methods in the Design Studio. Athens Journal of Humanities \& Arts, 1(1), 45-54. https://doi.org/10.30958/ajha.1-1-4

Piirto, J. (2004). Understanding Creativity. Scottsdale, AZ: Great potential Press. 


\section{Macrothink}

Global Journal of Educational Studies ISSN 2377-3936

Race, P. (2002). Why fix assessment: A discussion paper. Blog. Retrieved from http://www.sddu.leeds.ac.uk/online_resources/phil\%20assess.htm

Race, P. (2009). Designing Assessment to Improve Physical Sciences Learning. Hull: Higher Education Academy.

Race, P., Brown, S., \& Smith, B. (2005). 500 Tips on Assessment (2nd ed.). London: Routledge.

Rust, C. (2002). Purposes and Principles of assessment. Retrieved from http://www.brookes.ac.uk/services/ocsld/resources/briefing_papers/p_p_assessment.pdf

Saavedra, A. R., \& Opfer. (2012). Teaching and Learning $21^{\text {st }}$ Century Skills: Lessons from the Learning Sciences. RAND Corporation.

Satterfield, D., Kang, S. R., Ladjahasan, N., Quam, A., \& Bjorngaard, B. (2010). A Study on Design Careers and the impact of Gender. Retrieved from http://www.designresearchsociety.org/docs-procs/DRS2010/PDF/106.pdf

Sluijsman, D. M. A. (2002). Student involvement in assessment: The training of peer assessment skills. Heerlen: Omslag.

Spiller, D. (2012). Assessment Matters: Self-Assessment and Peer Assessment. Teaching Development Unit. The University of Waikato, Hamilton: New Zealand.

Struyven, K., Dochy, F., \& Janssens, S. (2005). Students' Perceptions about Evaluation and Assessment in Higher Education: A Review. Assessment and Evaluation in Higher Education, 30(4), 325-441. https://doi.org/10.1080/02602930500099102

Taylor, M. J., \& McCormack, C. (2004). Juggling Cats: Investigating Effective Verbal Feedback in Graphic Design Critiques. A paper presented to The Australian Council of University Art and Design Schools Annual Conference, 22-24 September 2004, Canberra, Australia. Retrieved from http://http://acuads.com.au/wp-content/uploads/2014/12/taylor_mccormack.pdf

Van den Bergh, V., Mortelmans, D., Spooren, P., Van Petegem, P., Gijbels, D., \& Vanthournout, G. (2006). New assessment modes within project-based Education - the

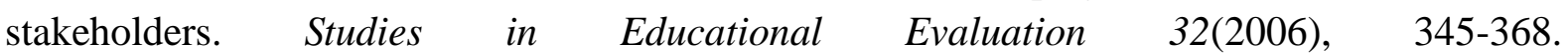
https://doi.org/10.1016/j.stueduc.2006.10.005

Willems, C. (2009). Objectifying the Subjective: Assessment and Feedback in Creative Arts Studio Learning and Teaching. In The 3rd National Forum on Studio Teaching, December 2009, Hobart, Tasmania. Retrieved from http://eprints.qut.edu.au/66673/ 
Appendix

\section{ASSESSMENT EVALUATION QUESTIONNAIRE}

\section{(Students)}

This questionnaire is intended to help the researcher find out the status quo as far as the assessment of students' knowledge and skills in the College of Art is concerned. All information provided will be kept confidential. Thank you.

Tick the appropriate box.

\section{Demographic information}

Gender

Age:

Department:

$$
\text { 18-20 }
$$

Male

21-23

Communication Design Integrated Rural Arts and Industry Publishing

Academic level:
Female

24-26

27 and above

Painting and Sculpture

Industrial Arts

300

For each statement, select the number that represents your preferred response using the scale below:

1: Strongly disagree 2: Disagree 3: Neutral $\quad$ 4: Agree $\quad$ 5: Strongly agree

\section{Assessment Practice}

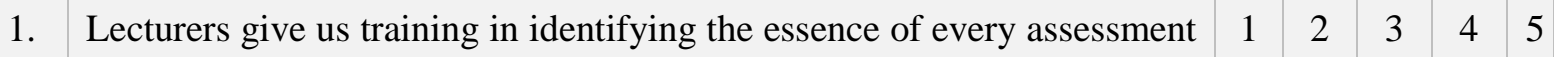
we are engaged in.

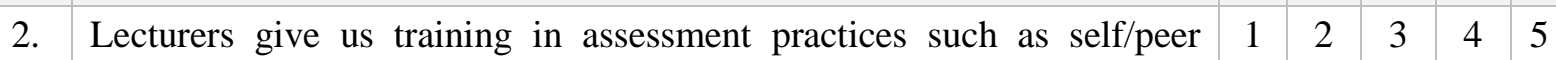
assessment.

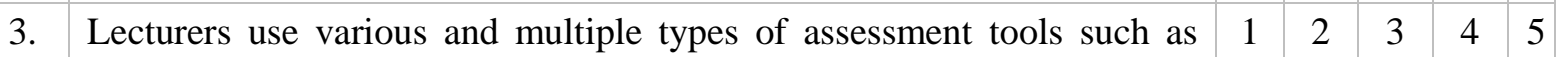
quizzes, tests, examinations and home works to assess our works.

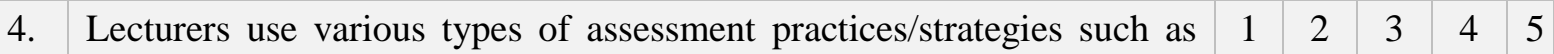
observation, portfolio review, self/peer assessment when our works.

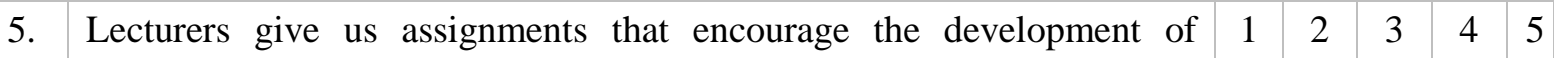
particular skills rather than mere memorisation of facts.

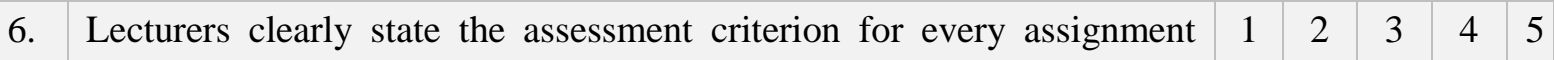
before we begin the work.

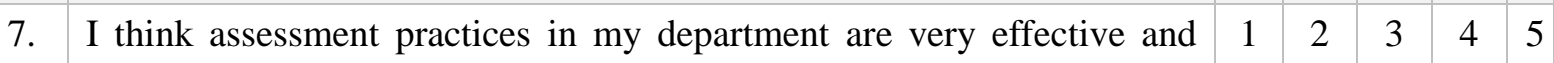
would help us improve our artistic skills.

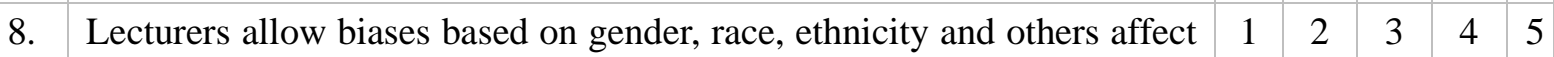
their sense of judgement during assessment.

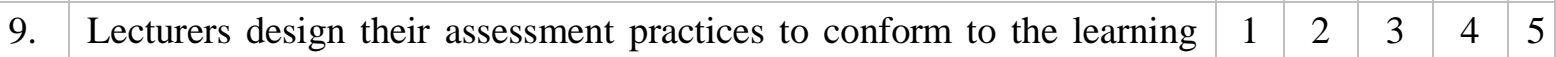
goals of the specific lesson taught.

10. Lecturers involve us in the assessment process by involving us in

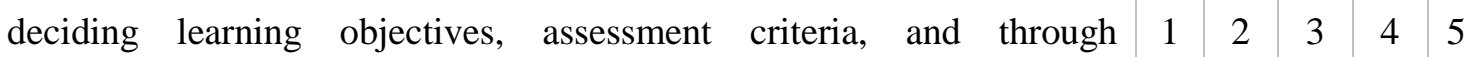
assessment practices such as self and peer assessment. 
11. People like parents, policy makers, professional bodies, journalists, \begin{tabular}{|l|l|l|l|l|l|} 
politicians and others must take keen interest in the assessment practices & 1 & 2 & 3 & 4 & 5
\end{tabular} in higher education.

\section{Assessment feedback}

\begin{tabular}{l|l|l|l|l|l|l|} 
12. After assignments, lecturers give us feedback about our performance. & 1 & 2 & 3 & 4 & 5 \\
\hline 13.
\end{tabular}

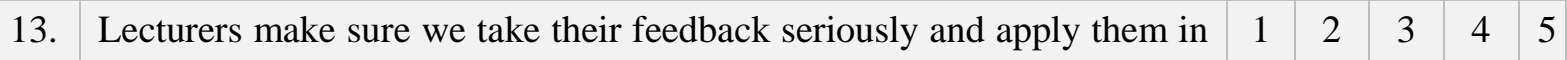
later assignments.

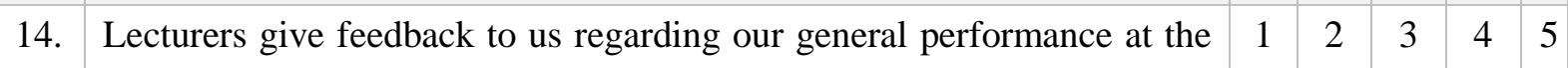
end of the semester.

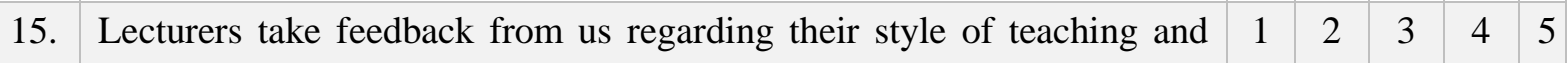
assessment.

\section{Assessment of artworks}

\begin{tabular}{l|l|l|l|l|l|l|} 
16. Assessment of students of the arts is more difficult than assessment of & 1 & 2 & 3 & 4 & 5
\end{tabular} students of other disciplines.

17. Art is a matter of individual taste and thus the open-mindedness of an \begin{tabular}{ll|l|l|l|l|} 
assessor could either encourage or thwart the creative abilities of a & 1 & 2 & 3 & 4 & 5
\end{tabular} student.

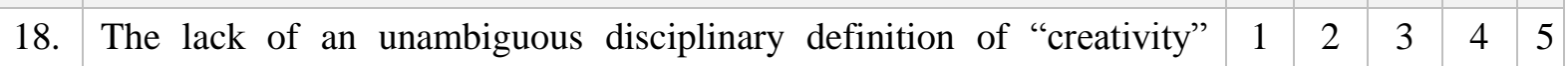
makes assessment of artworks more subjective than objective.

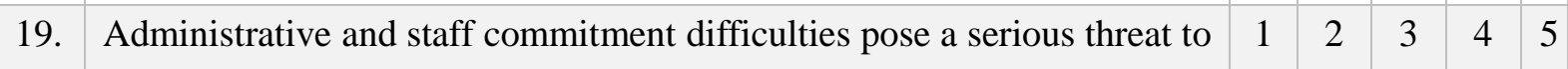
effective assessment of art students.

20. Skills required of art students such as originality, divergent and

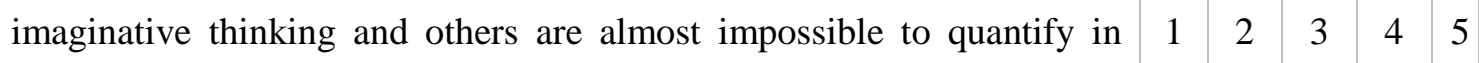
terms of marks.

Based on NEA (2005), Jia et al. (2009), Race (2002), Eshun and de Graft-Johnson (2011).

\section{Copyright Disclaimer}

Copyright for this article is retained by the author(s), with first publication rights granted to the journal.

This is an open-access article distributed under the terms and conditions of the Creative Commons Attribution license (http://creativecommons.org/licenses/by/3.0/). 